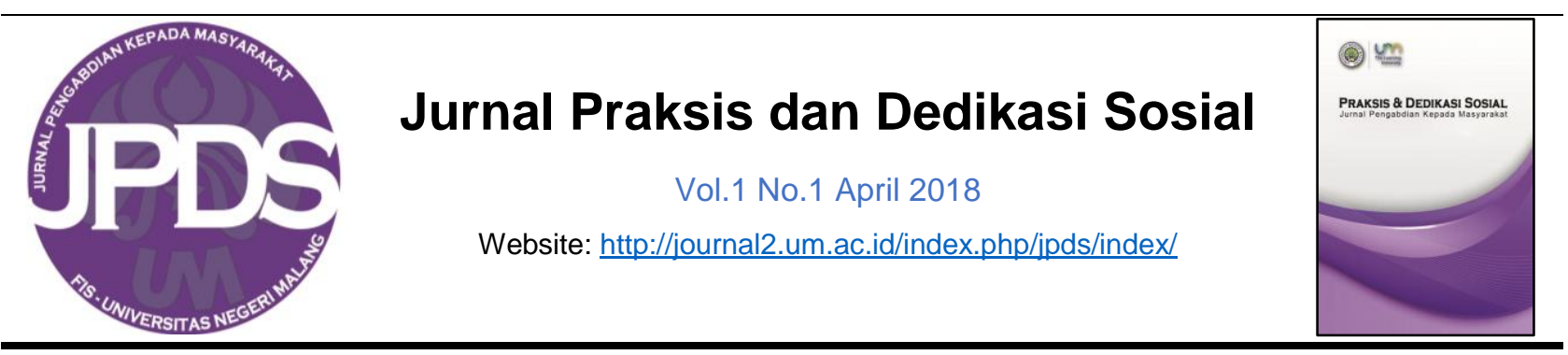

\title{
PELATIHAN PEMBUATAN PRODUK HUKUM DESA DI PEMERINTAHAN DESA KECAMATAN SUMBERPUCUNG KABUPATEN MALANG
}

\author{
Didik Sukriono', Desinta Dwi Rapita² \\ 1,2Jurusan Hukum dan Kewarganegaraan, Fakultas IImu Sosial, Universitas Negeri Malang. \\ Diterima 23 Maret 2018, dipublikasikan 30 April 2018.
}

\begin{abstract}
Abstrak
Undang-undang Nomor 6 Tahun 2014 tentang Desa mengakomodasi banyak hal yang muaranya untuk melindungi dan memberdayakan desa agar menjadi lebih kuat, maju, madiri dan demokratis. Dengan demikian, Desa diberikan kepercayaan, amanah dan tanggung jawab untuk mengelola wilayahnya. Salah satu wujud kewenangan desa untuk mengatur kepentingan masyarakatnya adalah melalui pembentukan produk hukum desa untuk mengatur penyelenggaraan pemerintahan desa, mengatur pelaksanaan pembangunan, pembinaan masyarakat, pemberdayaan masyarakat dan pelayanan umum. Hanya sayangnya belum semua desa menyusun peraturan desa, dan jika sudah membuat peraturan desa belum semua peraturan desanya sesuai dengan kaidah legalislative drafting. Hal ini terjadi hampir diseluruh desa di wilayah Kabupaten Malang, termasuk salah satunya yang berada di wilayah Kecamatan Sumberpucung. Metode palaksanaan kegiatan pengabdian adalah dengan analisis situasi, identifikasi masalah, pelaksanaan pelatihan sebagai pemecahan masalah serta refleksi dan evaluasi. Hasil pelatihan menunjukkan bahwa banyak desa yang belum mampu membuat produk hukum desa. Awalnya mereka tidak tahu konsep pembuatan produk hukum desa yang sesuai dengan legislative drafting, tapi akhirnya mereka paham dan dapat membuat produk hukum desa bagi desanya masing-masing.
\end{abstract}

Kata Kunci

Desa, Produk Hukum Desa, Legislative Drafting

(C) 2018 Penulis

\section{PENDAHULUAN}

Negara mengakui eksistensi desa sebagai wilayah otonom, baik desa sebagai sebuah kesatuan hukum maupun desa sebagai kesatuan adat di Nusantara dengan menerbitkan Undang-Undang Nomor 6 Tahun 2014 tentang Desa. Undang-Undang ini telah mengakomodasi banyak hal yang muaranya untuk melindungi dan memberdayakan desa agar menjadi kuat, maju, mandiri dan demokratis. Kedudukan desa ditempatkan pada posisi lebih terhormat dan diakui sebagai

\footnotetext{
${ }^{1}$ Surel Korespondensi: didik.sukriono.fis@um.ac.id
}

subyek yang berprakarsa. Selanjutnya di dalam Penjelasan Undang-Undang ini juga disebutkan, bahwa "Mengingat kedudukan, kewenangan, dan keuangan desa yang semakin kuat, penyelenggaraan pemerintahan desa diharapkan lebih akuntabel yang didukung oleh sistem pengawasan dan keseimbangan antara pemerintah desa dan lembaga desa". Artinya secara substantif Undang-Undang ini, memberikan kepercayaan, amanah dan tanggung jawab kepada berbagai pihak, yaitu jajaran pemerintahan nasional, daerah, lokal, 
terutama para pemangku kepentingan di desadesa (Penjelasan UU No 6 Tahun 2014).

Dengan demikian Desa sebagai kesatuan masyarakat hukum yang memiliki batas-batas wilayah, berwenang untuk mengatur dan mengurus kepentingan masyarakat setempat, berdasarkan asal-usul dan adat istiadat setempat yang diakui dan dihormati dalam sistem Pemerintahan Negara Kesatuan Republik Indonesia. Salah satu wujud kewenangan desa untuk mengatur kepentingan masyarakatnya adalah melalui pembentukan produk hukum desa. Salah satu tujuan dari pembentukkan produk hukum desa adalah dalam rangka penyelenggaraan pemerintahan desa, mengatur pelaksanaan pembangunan, pembinaan masyarakat, pemberdayaan masyarakat dan pelayanan umum. Oleh karena itu, pemahaman yang benar terhadap fungsi, kedudukan, dan tata cara pembuatan produk hukum desa menjadi hal penting yang harus diketahui oleh aparat pemerintah desa, agar produk hukum yang dibuat benar-benar dapat berfungsi sebagaimana mestinya dan tidak bertentangan dengan peraturan perundangan yang lebih tinggi (berlaku).

Merespon ketentuan di atas, Kementrian Dalam Negeri mengeluarkan Peraturan Menteri Dalam Negeri Republik Indonesia Nomor 111 tahun 2014 tentang Pedoman Teknis Peraturan di Desa. Jenis Peraturan yang diatur di Permendagri 111 tahun 2014 ini adalah tentang Peraturan Desa, Peraturan Bersama Kepala Desa, dan Peraturan Kepala Desa. Peraturan di Desa tersebut dijelaskan dalam Pasal 3 dan dilarang bertentangan dengan kepentingan umum, dan/atau ketentuan Peraturan Perundang-undangan yang lebih tinggi. Permendagri 111 tahun 2014 ini mencabut Peraturan Menteri Dalam Negeri Nomor 29 Tahun 2006 tentang Pedoman Pembentukan dan Mekanisme Penyusunan Peraturan Desa.

Peraturan Desa berisi materi pelaksanaan kewenangan desa dan penjabaran lebih lanjut dari peraturan perundang-undangan yang lebih tinggi. Peraturan bersama Kepala Desa berisi materi kerjasama desa. Sedang Peraturan Kepala Desa berisi materi pelaksanaan peraturan desa, peraturan bersama kepala desa dan tindak lanjut dari peraturan perundang-undangan yang lebih tinggi. Peraturan Desa, mencakup tiga bagian yaitu bagian Perencanaan, Penyusunan Peraturan Desa oleh Kepala Desa dan penyusunan Peraturan Desa oleh BPD, Pembahasan, Penetapan, Pengundangan dan Penyebarluasan.

Hanya sayangnya belum semua desa menyusun peraturan desa, dan jika sudah membuat peraturan desa belum semua peraturan desanya sesuai dengan kaidah legalislative drafting. Hal ini terjadi hampir diseluruh desa di wilayah Kabupaten Malang, termasuk salah satunya yang berada di wilayah Kecamatan Sumberpucung. Berdasarkan kewenangan yang cukup luas yang diberikan kepada Desa, seharusnya akan banyak produk hukum yang bisa dibuat oleh pemerintahan Desa di Sumberpucung. Sumberpucung merupakan kecamatan di Kabupaten Malang yang memiliki potensi wilayah yang cukup baik. Berada pada jalur 
penghubung antar kota, yaitu Kota MalangKota Blitar. Terdapat 7 Desa antara lain Desa Karangkates, Desa Sumberpucung, Desa Trenyang, Desa Jatigui, Desa Ngebruk, Desa Senggreng, dan Desa Sambigedhe. Apabila mengacu pada pemberlakuan Undangundang Desa pada tahun 2015, maka seharusnya saat ini minimal di setiap desa sudah terbit 3 (tiga) peraturan desa, yaitu: Peraturan Desa tetang RPJM Desa, Peraturan Desa tentang RKP Desa, dan Peraturan Desa tentang APB Desa. Namun kenyataannya belum seluruhnya (7 Desa di kecamatan Sumberpucung) yang mampu memenuhi minimal 3 Peraturan Desa tersebut. Produk hukum desa yang lainnya juga masih minim jumlahnya sedangkan 7 Desa di Kecamatan Sumberpucung ini memiliki potensi wilayah dan penduduk yang lumayan besar. Pemerintahan desa yang terdiri dari kepala desa, sekretaris desa, dan anggota BPD di wilayah Kecamatan Sumberpucung ternyata masih banyak yang belum memahami tentag konsep pembuatan produk hukum desa yang sesuai dengan kaidah legislative drafting. Termasuk ada juga yang masih ragu-ragu untuk membuat produk hukum desa, entah itu Peraturan Kepala Desa, Peraturan bersama Kepala Desa, maupun Peraturan Desa.

Pelatihan pembuatan produk hukum desa ini menjadi sangat penting dilaksanakan sebagai upaya untuk mensosialisasikan peraturan terbaru dan juga meningkatkan kabalilitas pemerintahan desa dalam pembuatan produk hukum desa. Beberapa langkah kegiatan pelatihan dilakukan oleh tim ini antara lain untuk mencapai tujuan kegiatan antara lain untuk: 1) mengetahui faktor-faktor yang melatarbelakangi kurangnya pemahaman Pemerintah Desa di Pemerintahan Desa Kecamatan Sumberpucung tentang pembuatan produk hukum desa; 2) memotivasi Pemerintah Desa di Kecamatan Sumberpuucng untuk membuat Produk Hukum Desa yang sesuai dengan kaidah legal drafting; meningkatkan pemahaman dan kemampuan perangkat desa untuk membuat produk hukum desa di Pemerintahan Desa Kecamatan Sumberpucung Malang.

\section{METODE}

Metode kegiatan yang dimaksud disini adalah pola atau sistem tindakan yang akan dilakukan, ataupun tahapan-tahapan yang perlu dalam menjalankan kegiatan pegabdian kepada masyarakat (Murdjito, 2012). Adapun tahapan-tahapan yang telah digambarkan pada gambar 1 .

Tahap awal yang dilakukan sebab pengabdian masyarakat merupakan kegiatan

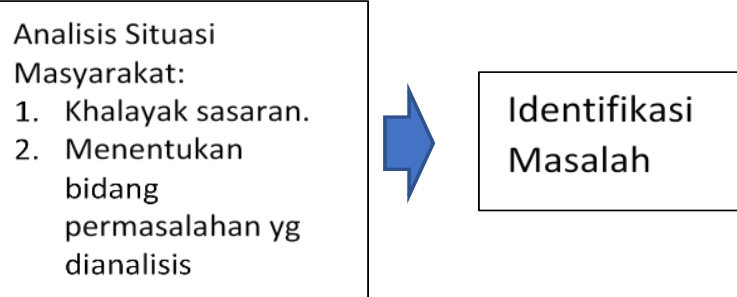

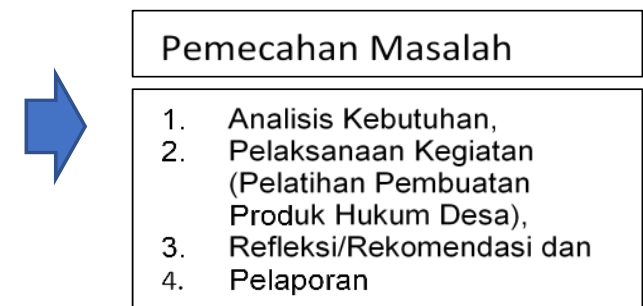

Gambar 1. Tahapan-tahapan kegiatan pengabdian 
yang harus dimulai dari niat untuk membantu masyarakat. Tahap ini dilakukaan dengan dua sub tahapan, yaitu: 1) menentukan khalayak sasaran dan 2) menentukan bidang permasalahan yang dianalisis. Sasaran kegiatan ini adalah Kepala Desa, Sekretaris Desa dan BPD di seluruh desa di Kecamatan Sumberpucung Malang. Pemilihan dan penetapan sasaran pelatihan ini mempunyai pertimbangan rasional-strategis dalam kaitannya mengembangkan desa yang notabene sudah diberikan keleluasaan oleh pemerintah untuk berkembang. Sedangkan bidang permasalahan yang dianalisis adalah secara terbatas hanya pada permasalahan pembuatan produk hukum desa. Dimana sebagian besar pemerintah desa (Kepala Desa) dan BPD (Badan Permusyawaratan Desa) di Kecamatan Sumberpucung belum memahami proses pembuatan Produk Hukum Desa yang sesuai dengan kaidah legal drafting.

Hasil dari kerja analisis yang mencakup sasaran dan bidang permasalahan tadi ialah dapat ditemukannya dan kemudian dapat dirumuskannya permasalahan yang dihadapi oleh sasaran kegiatan yaitu Pemerintah Desa di Kecamatan Sumberpucung, antara lain: 1) Faktor-faktor apa yang melatarbelakangi kurangnya pemahaman Pemerintah Desa di Pemerintahan Desa Kecamatan Sumberpucung tentang pembuatan produk hukum desa, 2) Bagaimanakah memotivasi Pemerintah Desa di Kecamatan Sumberpucung untuk membuat Produk Hukum Desa yang sesuai dengan kaidah legislative drafting, 3) Bagaimanakah meningkatkan pemahaman dan kemampuan perangkat desa untuk membuat produk hukum desa di Pemerintahan Desa Kecamatan Sumberpucung Malang. Tahap selanjutnya permasalahan yang sudah diidentifikasi perlu dipecahkan dan sekaligus mencapai tujuan (kondisi baru) yang telah ditetapkan. Semuanya itu perlu direncanakan dalam tahap ini, yang terdiri antara lain: 1) Analisis Kebutuhan, 2) Pelaksanaan Kegiatan (Pelatihan Pembuatan Produk Hukum Desa), 3) Refleksi/Rekomendasi dan 4) Pelaporan.

Pertama, analisis kebutuhan dilakukan dengan mempersiapkan beberapa produk hukum yang sudah ada dan dibuat oleh Pemerintah Desa dan BPD di Kecamatan Sumberpucung untuk selanjutnya dijadikan bahan yang bisa dianalisis dalam pelatihan. Narasumber menyusun makalah atau modul tentang pembuatan produk hukum desa yang sesuai dengan kaidah legal drafting. Selain itu juga dibuat atau disusun jadwal pelaksanaan kegiatan pelatihan. Kedua, pelaksanaan kegiatan adalah dimulai dengan pemberian materi yang disampaikan oleh narasumber dilanjutkan dengan menganalisis produkproduk hukum desa yang sudah ada agar sesuai dengan kaidah legislative drafting. Peserta pelatihan berdiskusi dengan narasumber untuk membuat produk hukum desa secara berkelompok yang sesuai dengan materi yang sudah diterima.

Ketiga, refleksi/ rekomendasi adalah peserta beserta narasumber memberikan refleksi, komentar dan rekomendasi atas produk hukum desa yang dibuat oleh peserta pada saat pelatihan, menjawab dan 
memberikan penjelasan kepada peserta pelatihan yang bertanya. Termasuk mencatat hal-hal yang perlu diperbaiki atau yang harus dipertahankan dalam pembuatan produk hukum desa untuk pembuatan produk hukum desa berikutnya. Keempat, pelaporan merupakan tahap akhir dari pelaksanaan pengabdian, yaitu dilakukan persiapan perangkat pelaporan sesuai dengan jadwal yang ditentukan.

\section{HASIL DAN PEMBAHASAN}

Hasil kegiatan pengabdian kepada masyarakat yang dilakukan di Pemerintahan Desa di Kecamatan Sumberpucung dapat dijelaskan secara berurutan mulai dari proses awal sampai dengan berakhirnya kegiatan. Pelatihan pembuatan produk hukum di pemerintahan Desa di Sumberpucung dilaksanakan secara bertahap. Tahap awal dari kegiatan ini adalah melakukan analisis situasi masyarakat untuk menentukan khalayak sasaran dengan bidang permasalahan yang dianalisis. Berdasarkan observasi akhirnya ditentukan permasalahan yang akan dicarikan solusi dengan kegiatan pelatihan ini adalah terbatas pada permasalahan pembuatan produk hukum desa. Hal ini disebabkan Karena pemerintahan desa yang terdiri dari Kepala Desa dan BPD (merupakan khalayak sasaran) dibeberapa desa di Kecamatan Sumberpucung belum sepenuhnya paham tentang proses pembuatan produk hukum, sehingga menyebabkan hampir setiap desa belum mempunyai produk hukum desa yang memadai untuk mengembangkan desanya.
Dari hasil analisis situasi masyarakat dan beberapa hasil identifikasi masalah, maka tim merancang pemecahan masalah. Pada tahap ini yang dilakukan oleh tim antara lain: 1) Analisis Kebutuhan, 2) Pelaksanaan Kegiatan, Refleksi/ Rekomendasi dan Pelaporan.

\section{Analisis Kebutuhan}

Analisis Kebutuhan dilaksanakan oleh tim dengan mempersiapkan dua hal, yaitu mengumpulkan beberapa produk hukum dari 7 desa di Kecamatan Sumberpucung dan menganalisis permasalahan yang ada di 7 desa itu untuk dicatikan solusinya. Ketujuh desa yang dimaksud antara lain: Desa Karangkates, Desa Sumberpucung, Desa Sambigedhe, Desa Ngebruk, Desa Trenyang, Desa Jatiguwi, dan Desa Senggreng. Produk hukum desa yang dihasilkan oleh masingmasing desa rata-rata hanya berupa Peraturan Desa, Peraturan Kepala Desa tentang RENSTRA, Peraturan Kepala Desa tentang penyusunan APBD. Sehingga masih banyak peraturan-peraturan yang belum dibuat oleh Desa. Misalnya saja tentang teknis penggunaan dana desa, tentang pengolahan lahan/sawah, tentang penggunaan tanah kuburan, tentang pelayanan publik di kantor desa, dan masih banyak lagi.

Hal ini menjadi persoalan yang lumayan menyita perhatian. Dana desa yang diberikan oleh pemerintah jumlahnya tidak sedikit. Sehingga itu harus dimanfaatkan dengan baik oleh pemerintahan desa. Jika produk hukum yang dihasilkan masih seperti itu maka tentunya efektifitas pelaksanaan pemerintahan juga tidak bisa dilakukan 
dengan baik. Apabila ini terjadi maka kesejahteraan masyarakat desa yang diharapkan pun juga akan sulit terwujud.

Terdapat beberapa faktor yang menyebabkan produktifitas pemerintahan desa dalam pembuatan produk hukum masih rendah, antara lain sumber daya manusia (pembuat produk hukum) yang masih minim pengatahuan tentang proses pembuatan produk hukum, tidak adanya harmonisasai antara Pemerintah Desa dengan BPD yang padahal mereka harusnya bisa bekerjasama untuk membuat produk hukum desa, dan permasalahan lainnya. Dari beberapa hasil analisis ini maka menurut penulisi perlu diadakan pelatihan pembuatan produk hukum di pemerintahan desa di kecamatan sumberpucung. Khalayak sasarannya adalah seluruh Kepala Desa Bersama sekretaris desa dan anggota BPD dari 7 (tujuh) desa di Kecamatan Sumberpucung.

\section{Pelaksanaan Kegiatan}

Kegiatan pelatihan pembuatan produk hukum desa oleh pemerintahan desa di Kecamatan Sumberpucung ini dilaksanakan pada tanggal 4 Mei 2017. Sesuai dengan hasil koordinasi dengan petugas di Kecamatan, maka pelatihan dilaksanakan di aula Kecamatan Sumberpucung. Kegiatan dilaksanakan mulai pukul 08.00 WIB s.d pukul 15.30 WIB. Peserta undangan yang datang ternyata melebihi dari target, awalnya sesuai undangan masing-masing desa diundang 3 orang (Kepala Desa, Sekretaris Desa, dan satu Anggota BPD), namun pada saat pelaksanaan ternyata yang datang lebih dari itu. Ada desa yang mengajak lebih dari satu anggota BPD, ada juga yang mengajak perangkat desa lain. Selain itu turut diundang pendamping desa di Kecamatan Sumberpucung dan juga beberapa orang dari Kecamatan Sumberpucung yang dilibatkan dalam kegiatan ini. Sehingga total jumlah peserta menjadi 50 orang.

Kegiatan pelatihan ini dilaksanakan sesuai dengan jadwal yang sudah dibuat. Pukul 07.00 s.d. pukul 08.00 WIB dilakukan

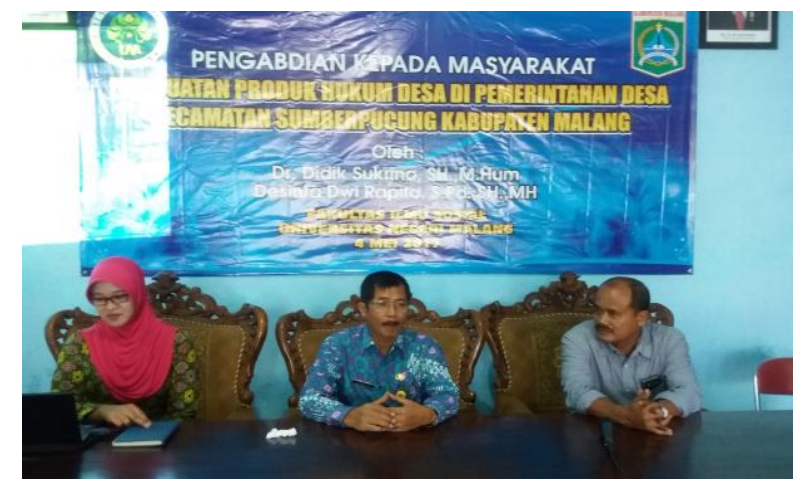

Gambar 2. Pembukaan Oleh Camat

Sumberpucung (dokumentasi pribadi, 2017).

registrasi peserta oleh tim. Selanjutnya pukul 08.00 WIB dimulai acara pelatihan dengan diawali pembukaan oleh Camat Sumberpucung, Bapak Moch. Arifin, S.Sos., MM.

Setelah itu dilanjutkan dengan pemberian materi pelatihan oleh Dr. Didik Sukriono, S.H.,M.H. dan Desinta Dwi Rapita, S.Pd.,S.H.M.H. Materi yang dilatihkan antara lain: 1) Konsep Produk Hukum Desa, 2) Jenisjenis Produk Hukum Desa, 3) Kaidah Legal Drafting, 3) Praktik Pembuatan Produk Hukum Desa.

Pada sesi pertama, pemateri sangat interaktif menyampaikan materinya, sehingga peserta menjadi sangat antusias. Peserta tidak segan-segan bertanya jika ada hal-hal yang perlu dijelaskan lebih mendalam. Peserta dari Desa Sambigede menyampaikan 
persoalan di desanya yang salah satunya tidak ada harmonisasi antara Kepala Desa dengan BPD. Di saat yang bersamaan anggota BPD Sambigede langsung menanggapi. Disinilah pemateri menjelaskan tupoksi Kepala Desa dan hubungannya dengan BPD dalam proses pembuatan produk hukum desa. Akhirnya kesalahpahaman yang selama ini terjadi yang menganggap bahwa Kepala Desa lah yang paling berkuasa di Desa akhirnya bisa dipahamkan oleh pemateri bahwa antara Kepala Desa dengan BPD harusnya berkolaborasi dalam pembuatan produk hukum desa. Pertanyaan berikutnya dari sekretarisi desa Jatigui yang bertanya bagaimana cara menuliskan nomor pada peraturan desa atau kepala desa dan pencantuman nama pejabat di dalam peraturan tersebut. Pada pertanyaan ini Dr.

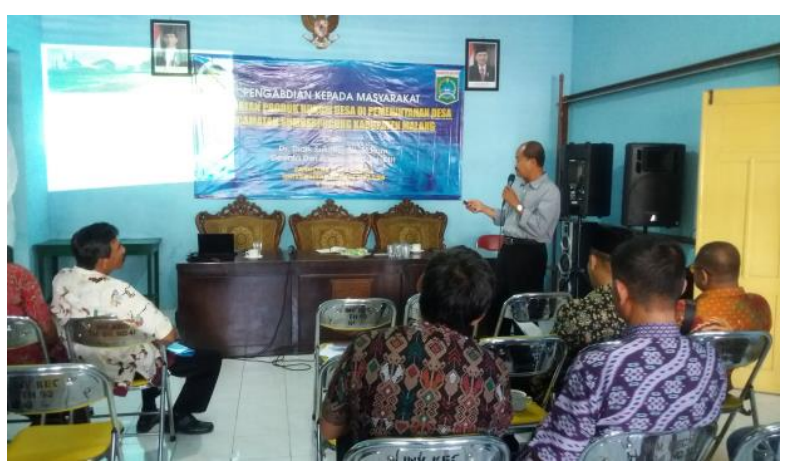

Gambar 3. Penyampaian materi oleh Dr. Didik Sukriono, SH.,MH (dokumentasi pribadi 2017).

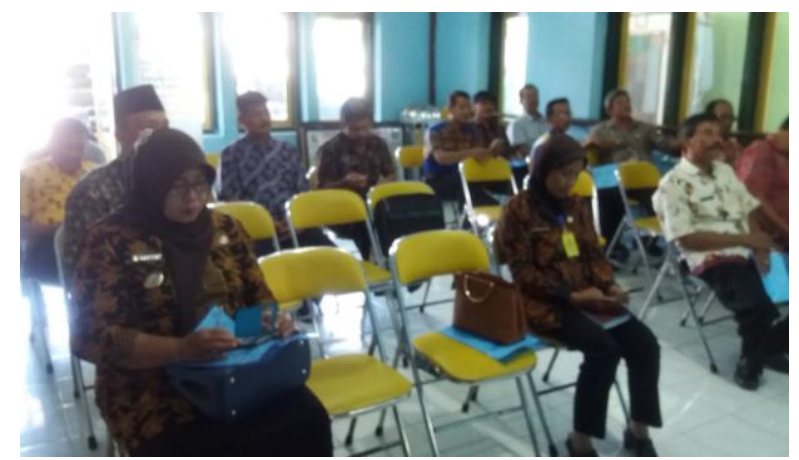

Didik Sukriono menjelaskan mengenai kaidah penulisan dan memberikan copy file template peraturan desa. Penjelasan mendalamnya akan diberikan pada sesi berikutnya.

Sesi kedua dilanjutkan dengan praktik pembuatan Produk Hukum Desa. Pada tahap pelatihan ini, dititikberatkan pada kemampuan untuk mengidentifikasi permasalahanpermasalahan yang muncul di desa dan perlu dibuatkan produk hukumnya, menganalisis bentuk produk hukum desa yang mana yang bisa dibuat dan sesuai dengan hasil identifikasi, dan membuat produk hukum desa dengan acuan kaidah penulisan produk hukum yang sesuai dengan kaidah legal drafting. Peserta mengikuti kegiatan pelatihan dengan baik dan mengikuti semua intruksi dari pemateri. Peserta dibagi berdasarkan Desa nya masing-masing. Mereka diberikan

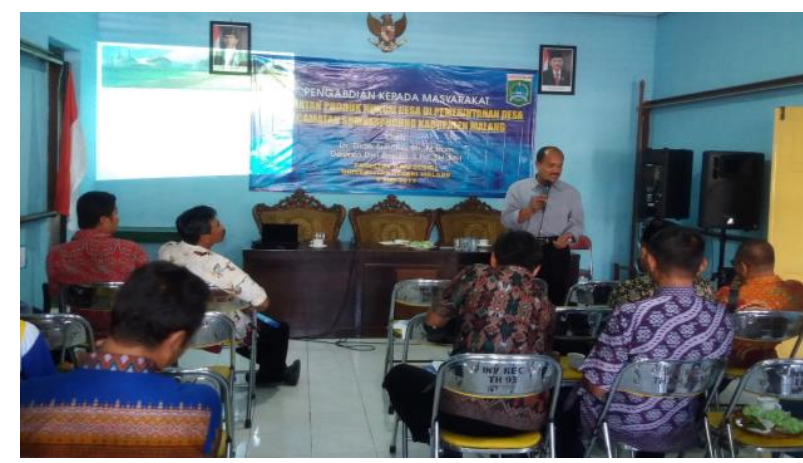

Gambar 4. Sesi Tanya-jawab peserta dengan pemateri (dokumentasi pribadi, 2017).

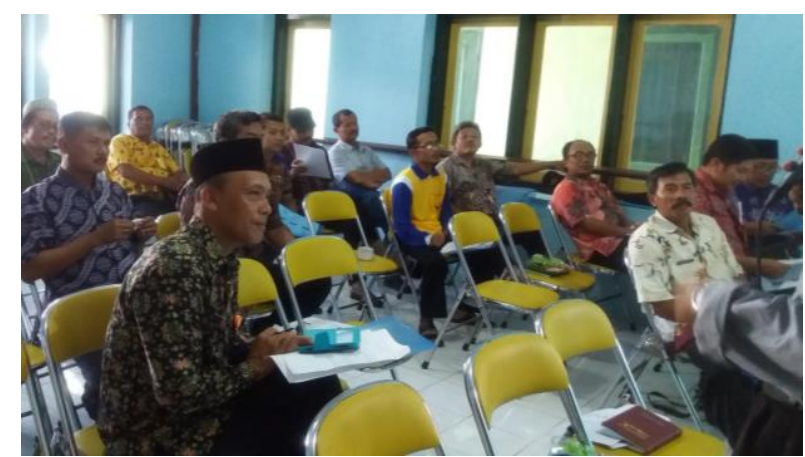

Gambar 5 \& 6. Peserta Pelatihan memperhatikan penjelasan dari narasumber (Dr. Didik Sukriono, M.Hum dan Desinta Dwi Rapita, MH (dokumentasi pribadi, 2017). 
tugas menganalisa permasalahan dari masing-masing desa yang perlu dan memungkinkan dibuatkan peraturan hukumnya. Pada beberapa hal yang kurang jelas, peserta langsung meminta bantuan kepada pemateri. Setelah itu masing-masing kelompok menentukan produk hukum desa jenis apa yang ingin mereka buat. Dengan didampingi narasumber dan dibantu oleh

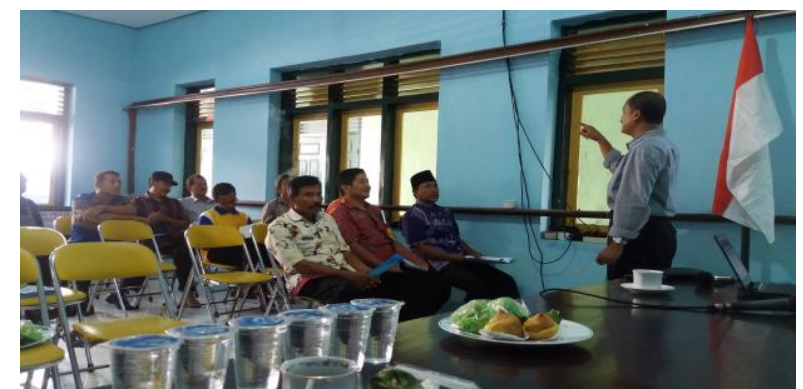

Gambar 7. Dr. Didik Sukriono memberikan penjelasan mengenai tahapan praktik pembuatan draf produk hukum desa (dokumentasi pribadi, 2017).

pendamping desa, tiap kelompok (desa) membuat draf peraturan. Ada yang membuat peraturan desa dan ada yang membuat peraturan kepala desa. Sedangkan draf peraturan Bersama kepala desa belum sempat dibuat sebab baru akan dianalisis halhal mana yang sama yang perlu dibuatkan peraturan bersama kepala desa. Semua tahapan pelatihan dapat dijalankan dengan baik, semua bekerjasama dan mengikuti kaidah legislative drafting yang materinya sudah disampaikan di sesi pertama.

Pelatihan ini berakhir pada tahap pembuatan draf peraturan yang nantinya akan menjadi bahan yang bisa diteruskan penyelesaiannya di desa oleh pemerintahan desa masing-masing. Mereka akan meneruskan praktik pembuatan produk hukum desa ini sesuai dengan materi yang sudah diterima dari pemateri. Karena waktu yang dimiliki terbatas sedangkan banyak dari perwakilan desa meminta untuk kegiatan pendampingan bisa dilanjutkan lagi, maka kelanjutan dari kegiatan pelatihan ini diputuskan dengan melalui pendampingan baik secara langsung maupun tidak langsung oleh pemateri yang difasilitasi oleh pendamping desa. Perangkat desa mengusulkan kepada sekretaris kecamatan agar mengagendakan kegiatan pelatihan seperti ini karena dirasa sangat penting bagi perangkat desa. Selain itu dengan adanya pelatihan seperti ini diharapkan dapat menghasilkan produk-produk hukum yang baik sehingga bisa meningkatkan kesejahteraan rakyat. Dari usulan yang disampaikan, langsung ditanggapi oleh Sekretaris Kecamatan, Bapak Trilambang. Bapak Trilambang akhirnya mengajak pemateri untuk berkoordinasi mengenai kegiatan tindak lanjut dari kegiatan pelatihan ini.

\section{Refleksi/ Rekomendasi}

Tahap berikutnya setelah pelaksanaan kegiatan pelatihan adalah melaksanakan refleksi. Refleksi ini dilaksanakan secara bersama-sama oleh tim dan panitia kecamatan yang terdiri dari camat, sekretaris camat, dan perwakilan dari sub bagian hukum Kecamatan Sumberpucung. Hasil refleksi antara lain kegiatan pelatihan sudah dilaksanakan dengan baik sesuai dengan tahapan-tahapan yang sudah direncanakan. Peserta antusias dan mendapatkan manfaat dari kegiatan pelatihan. Karena begitu banyak usulan yang menginginkan kegiatan bisa ditindaklanjuti, maka direkomendasikanuntuk dapat dilaksanakan kegiatan serupa 
Pelatihan Pembuatan Produk Hukum Desa di Pemerintahan Desa...

dikemudian hari dan difasilitasi langsung oleh Kecamatan Sumberpucung.

\section{Pelaporan}

Pada tahap pelaporan ini, tim dengan terlebih dahulu menyiapkan hasil kegiatan beserta analisisnya dan juga hasil refleksi. Setelah itu tim menyusun laporan sesuai dengan kaidah yang ditentukan dalam penulisan laporan. Laporan disampaikan ke lembaga sesuai dengan ketentuan yang telah diberikan oleh lembaga. Untuk selanjutnya laporan yang Sudha dibuat dapat dijadikan acuan maupun referensi untuk kegiatankegiatan lain sebagai upaya untuk mengembangkan keilmuan dan pengalaman.

Ada beberapa faktor yang melatarbelakangi kurangnya pemahaman Pemerintah Desa di Pemerintahan Desa Kecamatan Sumberpucung tentang pembuatan produk hukum, antara lain: 1) Tidak ada kegiatan yang pelatihan atau sejenisnya yang berkesinambungan yang berkaitan dengan pembuatan produk hukum desa, 2) Jika ada kegiatan pelatihan yang mengundang Kepala Desa seringkali yang datang bukan kepala desa, 3) terjadi miskomunikasi dan disharmonisasi antara Kepala desa dengan BPD yang pada akhirnya tidak bisa dihasilkan produk hukum desa yang baik.

Beberapa faktor di atas akhirnya berdampak pada produktifitas pemerintahan desa. Banyak hal yang belum dibuatkan produk hukum desa nya oleh pemerintahan desa. Mereka masih ragu untuk mengembangkan peraturan desa yang sudah ada. Masih ada beberapa perangkat desa dan
BPD yang mengalami disharmonisasi pada saat pembuatan produk hukum desa. Hal ini lah yang pada akhirnya membuat tim merasa perlu melakukan kegiatan pengabdian kepada masyarakat ini.

Berdasarkan UU Nomor 6 Tahun 2014 tentang Desa, maka setiap desa mempunyai kewenangan untuk membuat peraturan atau produk hukum desa nya masing-masing. Undang-undang ini merupakan bentuk pengakuan negara atas eksistensi desa sebagai sebuah wilayah otonom, baik desa sebagai sebuah kesatuan hukum maupun desa sebagai kesatuan adat di Nusantara. Tim Pengabdian berusaha menjelaskan dan memberikan pemahaman kepada Pemerintah Desa (Peserta Pelatihan) khususnya mengenai ketentuan yang terdapat dalam Peraturan Menteri Dalam Negeri Republik Indonesia Nomor 111 tahun 2014 tentang Pedoman Teknis Peraturan di Desa. Peserta mengikuti kegiatan pelatihan dengan sangat antusias. Kegiatan pelatihan dibagi mnejadi dua sesi, yang pertama sesi materi yang disampaiakn oleh tim. Sesi kedua pelatihan atau praktik membuat pproduk hukum desa.

Peserta yang menjadi target pelatihan adalah seluruh kepala desa, sekretaris desa dan anggota BPD dari 7 (tujuh) desa di Kecamatan Sumberpucung. Total seluruh peserta dan perangkat kecamatan yg juga mengikuti kegiatan adalah 50 orang. Pada saat pelaksanaan peserta datang sepenuhnya, namun saat proses pelatihan ada beberapa yang ijin meninggalkan tempat untuk kegiatan di desa nya. Namun mereka tidak lama kemudian kembali lagi untuk 
mengikuti kegiatan sampai dengan berakhirnya kegiatan. Banyak pertanyaan yang disampaiakan oleh peserta dan bisa dijawab dan dijelaskan oleh pemateri. Kegiatan pelatihan berjalan dengan baik dan lancar. Peserta menghasilkan draf produk hukum. Masing-masing desa berbeda-beda produk hukum yang dihasilkan. Ada yang membuat draf peraturan desa, ada yang membuaut peraturan kepala desa, dan beberapa contoh keputusan kepala desa. Peserta merasa termotivasi dan berkeinginan untuk mempraktikkan hasil kegiatan pelatihan ini di desa nya masing-masing.

Hasil refleksi antara lain: peserta merasa puas dan mendapat manfaat dari kegiatan ini, camat dan sekretaris camat merasa perlu untuk acara ini ditindak lanjuti lagi, selain itu juga ada usulan dari peserta untuk mengadakan pendampingan lanjutan dalam pembuatan produk hukum desa di Kecamatan Sumberpucung ini. Akhirnya disepakati akan ada kegiatan berikutnya nantinya akan diprakarsai oleh Kecamatan Sumberpucung.

\section{KESIMPULAN}

Dari keseluruhan kegiatan pelatihan "Pelatihan Pembuatan Produk Hukum Desa di Pemerintahan Desa Kecamatan Sumberpucung Kabupaten Malang" ini dapat disimpulkan sebagai berikut.

Faktor yang melatarbelakangi kurangnya pemahaman Pemerintah Desa di Pemerintahan Desa Kecamatan Sumberpucung tentang pembuatan produk hukum, antara lain: 1) Tidak ada kegiatan yang pelatihan atau sejenisnya yang berkesinambungan yang berkaitan dengan pembuatan produk hukum desa, 2) Jika ada kegiatan pelatihan yang mengundang Kepala Desa seringkali yang datang bukan kepala desa, 3) terjadi miskomunikasi dan disharmonisasi antara Kepala desa dengan BPD yang pada akhirnya tidak bisa dihasilkan produk hukum desa yang baik.

Kegiatan pelatihan berjalan dengan baik dan sesuai dengan rencana. Semua materi kegiatan dapat disampaikan dengan baik oleh tim pengabdi. Selama kegiatan ini berlangsung para peserta menunjukkan antusias dan aktivitas yang tinggi. Peserta termotivasi untuk membuat produk hukum desa yang sesuai dengan kaidah penulisan legislative drafting.

Melalui kegiatan pelatihan, peserta dapat menyusun Produk Hukum Desa, antara lain Peraturan Desa, Peraturan Kepala Desa, dan Peraturan Bersama Kepala Desa.

\section{DAFTAR PUSTAKA}

Huda, Ni'matul. 2011. Hukum Pemerintahan Desa dalam Konstitusi Indonesia Sejak Kemerdekaan Hingga Reformasi.

Koentjaraningrat. 1984. Masyarakat Desa di Indonesia,Jakarta: LPFE UI.

Murdjito, Gatot. 2012. Pelatihan Metode Pengabdan Masyarakat Tahun 2012, (online), (www.slideshare.net), diakses Februari 2017).

Sukriono, Didik. 2014. Undang Undang Desa dan Permasalahan Sosial Budaya, Jurnal Transisi Edisi 9, Instran Publishing Malang.

Wahono, Francis. 2001. "Bersekongkol atau Saling Kontrol", dalam Duto Sosialismanto, Hegemoni Negara, Ekonomi Politik Pedesaan di Jawa, Yogyakarta: LAPERA Pustaka.

Undang-Undang No 11 Tahun 2011 Tentang Pembentukan Peraturan PerundangUndangan.

Undang-Undang Nomor 6 Tahun 2014 Tentang Desa, Bandung: Fokusmedia. 
Penjelasan Undang Undang Republik Indonesia Nomor 6 Tahun 2014 Tentang Desa, Fokusmedia Bandung, 2014.

Peraturan Pemerintah No 47 Tahun 2015 Tentang Perubahan Atas Peraturan Pemerintah No 43 Tahun 2014 Tentang Peraturan Pelaksanaan Undang-Undang No 6 Tahun 2016 Tentang Desa.
Peraturan Menteri Dalam Negeri Nomor 111 Tahun 2014 tentang Pedoman Teknis Penyusunan Peraturan Di Desa.

Peraturan Pemerintah No 22 Tahun 2016 Tentang Perubahan Atas Peraturan Pemerintah No 60 Tahun 2014 Tentang Dana Desa yang Bersumber dari APBN. 